\title{
Breastfeeding Self-Efficacy and the Use of Prescription Medication: A Pilot Study
}

\author{
Cynthia Mannion and Deborah Mansell \\ School of Nursing, Faculty of Nursing, University of Calgary, 2290-2500 University Drive NW, Calgary, AB, Canada T2N 1N4 \\ Correspondence should be addressed to Cynthia Mannion, cmannion@ucalgary.ca
}

Received 8 July 2011; Revised 26 September 2011; Accepted 30 September 2011

Academic Editor: Gideon Koren

Copyright ( $) 2012$ C. Mannion and D. Mansell. This is an open access article distributed under the Creative Commons Attribution License, which permits unrestricted use, distribution, and reproduction in any medium, provided the original work is properly cited.

Objective. To examine the association of self-efficacy, perception of milk production, and lactating women's use of medication prescribed to increase breast milk in a cohort of 18-40-year-old mothers over six months. Methods. Mothers $(n=76)$ attending community clinics completed the Breastfeeding Self-Efficacy Scale and the Humenick/Hill Lactation Scale, a measure of perceived milk production, three times. Results. Domperidone, a dopamine antagonist, was used by $28 \%$ of participants. On average, those using domperidone had lower self-efficacy scores than those not using it $(P<0.05)$ and were more likely to have used formula (Pearson chi-square test statistic $=6.87, \mathrm{df}=1, P<0.05$ ). Breastfeeding self efficacy and perception of milk production were positively correlated. Conclusion. Breastfeeding assessment conducted prior to prescription of galactogogues is recommended for mothers and healthy term babies. Following Baby-Friendly hospital protocols and increasing self-efficacy for lactating women may be most effective in sustaining breastfeeding. Risks and benefits of various galactogogues are discussed.

\section{Introduction}

Breastfeeding is the optimal form of nutrition for term and preterm infants [1-3]. Short- and long-term benefits are associated with reduced sudden infant death syndrome; positive immunological effects; reductions in the risks of otitis media, nonspecific gastroenteritis, severe lower respiratory tract infections, atopic dermatitis, obesity, type 1 and 2 diabetes, and childhood leukemia $[1,4]$. However, exclusive breastfeeding, defined by the Public Health Agency of Canada [5] as "breastfeeding with no other liquid or solid given to the infant," is short-lived among lactating mothers everywhere. In a study comparing results from the Listening to Mothers II (LTM2; $n=1563$ ) and the Maternal Experience Survey (MES; $n=6421$ ) conducted in the United States 2005 and Canada 2006, respectively, rates of exclusive breastfeeding in hospital postpartum were reported as $61.2 \%$ and $75.4 \%$ [6]. At three months this rate dropped to $42.5 \%$ for the LTM2 and $51.7 \%$ for the MES. At six months both surveys reported exclusive breastfeeding rates of less than 20\% [6]. Maintenance of breastfeeding seems challenging for many women. Perception of insufficient breastmilk production may contribute to cessation rates [ 7 , 8].

Galactogogues are substances that increase milk volume by enhancing the rate of milk production and include both medications such as domperidone, metoclopramide, and herbs such as fenugreek, blessed thistle, and fennel (Tables 1 and 2). Common indications for galactogogues usually occur where lactation is nonexistent or threatened by known causes. This includes induction of lactation for adoptive mothers, relactation after weaning, maternal hypothyroidism, stimulate lactation in women with neonates in the neonatal intensive care unit, and for mothers who express milk by hand or pump $[7,9,12,13]$.

Anecdotally, there appears to be a trend for health care professionals to recommend pharmacological measures for mothers in the community who present with reported low milk supply issues. Reported low milk supply may be alleviated by modifying maternal self-efficacy through skill improvement and knowledge development [2]. The efficacy of galactogogues on the maintenance of breastfeeding for 
TABLe 1: Prescription drugs used to increase breastmilk production.

\begin{tabular}{|c|c|c|c|}
\hline Drug (trade name) & Intended use & Mechanism & Potential side effects \\
\hline Domperidone (Motilium) & $\begin{array}{l}\text { Antiemetic treatment of } \\
\text { reflux disease }\end{array}$ & $\begin{array}{l}\text { Peripheral } \\
\text { dopamine } \\
\text { antagonist }\end{array}$ & $\begin{array}{l}\text { (i) Maternal cardiac arrhythmia } \\
\text { (ii) Possible neurological side effects in infants } \\
\text { (iii) Dry mouth, abdominal cramps, and headache } \\
\text { (iv) Not approved in the United States }\end{array}$ \\
\hline Metoclopramide (Maxeran) & Antiemetic & $\begin{array}{l}\text { Dopamine } \\
\text { antagonist }\end{array}$ & $\begin{array}{l}\text { Drowsiness, restlessness, fatigue, anxiety, insomnia, } \\
\text { depression, sedation, and pseudo-Parkinsonism } \\
\text { Pediatric: prolonged clearance in infants which can } \\
\text { result in high serum levels and a risk for } \\
\text { methemoglobinemia. Side effects are more common } \\
\text { in children }\end{array}$ \\
\hline Sulpiride (Eglonyl) & $\begin{array}{l}\text { Schizophrenia } \\
\text { Antipsychotic } \\
\text { Antidepressant }\end{array}$ & $\begin{array}{l}\text { Selective dopamine } \\
\text { antagonist }\end{array}$ & $\begin{array}{l}\text { Extrapyramidal reactions and sedation in adults as } \\
\text { well as suspected potential neonatal } \\
\text { endocrinological effects } \\
\text { Excreted in breastmilk }\end{array}$ \\
\hline Chlorpromazine (Thorazine) & Antipsychotic & Increases prolactin & $\begin{array}{l}\text { Sedation, lethargy, and risk of apnea } \\
\text { Pediatric: SIDS }\end{array}$ \\
\hline $\begin{array}{l}\text { HGH human growth } \\
\text { hormone (Somatotropin) }\end{array}$ & $\begin{array}{l}\text { Hormone purified } \\
\text { polypeptide of } \\
\text { recombinant DNA }\end{array}$ & $\begin{array}{l}\text { Stimulates milk } \\
\text { production }\end{array}$ & $\begin{array}{l}\text { Hypoglycemia } \\
\text { Pediatric: absorption from breastmilk is unlikely }\end{array}$ \\
\hline $\begin{array}{l}\text { THR thyrotrophin releasing } \\
\text { hormone }\end{array}$ & $\begin{array}{l}\text { Treatment of } \\
\text { hypothyroidism }\end{array}$ & $\begin{array}{l}\text { Affects prolactin } \\
\text { release }\end{array}$ & $\begin{array}{l}\text { Theoretically may cause hyperthyroid condition in } \\
\text { infants }\end{array}$ \\
\hline Oxytocin (Pitocin Syntocinon) & $\begin{array}{l}\text { Endogenous } \\
\text { nonapeptide hormone }\end{array}$ & $\begin{array}{l}\text { Stimulates milk } \\
\text { ejection reflex }\end{array}$ & $\begin{array}{l}\text { Hypotension, hypertension, water intoxication and } \\
\text { excessive uterine contractions, bradycardia, and } \\
\text { arrhythmias } \\
\text { Pediatric: neonatal jaundice }\end{array}$ \\
\hline
\end{tabular}

Metoclopramide [9], Domperidone [10], Motilium [9, 10], and Sulpiride [11].

healthy term newborns and their mothers is unknown. Galactogogues are more commonly used for re-lactation and lactogenesis for adoptive mothers and mothers of babies in neonatal intensive care $[13,14]$.

High intention and initiation rates of breastfeeding, exclusive or otherwise, are rarely maintained beyond six months [15]. There are a multitude of reasons women stop breastfeeding including a lack of self-confidence in breastfeeding skills, lack of functional support, low spousal support, desire to smoke, sore nipples, postpartum depression, and maternal nutritional concerns [15-17]. Women who have experienced breast surgery, most commonly breast reduction and augmentation, may not be able to produce enough milk [18]. Maternal obesity has been implicated in delayed lactogenesis [19].

The use of formula in hospitals has been linked with low breastfeeding success rates [20]. The Baby-Friendly Hospital Initiative (BFHI) was introduced by the World Health Organization and UNICEF to increase breastfeeding rates and recommends the reduction of formula use in hospitals to promote breastfeeding [21]. In 1996, in Belarus, Kramer et al. conducted a randomized trial using the model of the Baby-Friendly Hospital initiative as an intervention and found that exclusive breastfeeding and duration increased for the first year of infants' lives given exposure to BFHI compared with standard of care received in control hospitals [22]. In 2005, it was also found that following BFHI steps, duration of breastfeeding increased. Of note, their sample consisted of women who may have been interested in exclusive breastfeeding and selected hospitals with BFHI [23]. At the same time, there was high media coverage on BFHI in Sweden where the study took place so awareness might have been heightened as breastfeeding rates in nonBFHI hospitals also rose [23].

The use of formula in hospital and at home has long been considered a detriment to exclusive breastfeeding and breastmilk production. However, formula is available in all hospitals as there are women who do not breastfeed. A national survey conducted in the United States reported that women choose not to breastfed because of personal preference $(66.3 \%)$, they face current medical/physical problems (14.9\%), feeding multiples or failed breastfeeding [24-26].

Maintenance of exclusive and partial breastfeeding is challenging for many women. Worldwide, the most common reason reported by mothers for early cessation of breastfeeding is maternal perception of insufficient milk production $[8,13,24-32]$. Insufficient milk production, often referred to as insufficient milk syndrome (IMS) was initially described by Gussler and Briesmeister in 1980 and was quickly recognized by the World Health Organization as the world's largest threat to the continuation of breastfeeding [8]. The prevalence of perceived insufficient milk production by mothers is not precisely known but has been reported between $30 \%$ and $80 \%$ [32]. This reason is associated with the highest discontinuation of breastfeeding occurring as early as 1-4 weeks postpartum [33]. Maternal perception of insufficient milk production is almost never validated by measured milk volume but is a prime influence in maternal 
TABLE 2: Herbs commonly associated with galactogogue properties and known interactions.

\begin{tabular}{|c|c|c|c|c|}
\hline Herbals & Intended use (main effect) & Potential side effects & Potential interactions & Contraindications \\
\hline $\begin{array}{l}\text { Alfalfa* (Medicago } \\
\text { sativa) }\end{array}$ & $\begin{array}{l}\text { Tonic } \\
\text { Rejuvenative } \\
\text { Diuretic }\end{array}$ & $\begin{array}{l}\text { Diarrhea } \\
\text { Reversible pancytopenia } \\
\text { Reactivates-systemic } \\
\text { Lupus }\end{array}$ & Immune modulators & $\begin{array}{l}\text { Pregnancy } \\
\text { Allergies }\end{array}$ \\
\hline $\begin{array}{l}\text { Anise* (Pimpinella }^{*} \\
\text { anisum) }\end{array}$ & $\begin{array}{l}\text { Expectorant } \\
\text { Antispasmodic } \\
\text { Antiseptic } \\
\text { Antiflatulence }\end{array}$ & Seizures & $\begin{array}{l}\text { Anticoagulants } \\
\text { MAO inhibitors oral } \\
\text { contraceptives }\end{array}$ & $\begin{array}{l}\text { Pregnancy: } \\
\text { abortifacient }\end{array}$ \\
\hline $\begin{array}{l}\text { Black seed caraway } \\
\text { (Carum carvi) }\end{array}$ & $\begin{array}{l}\text { Dyspepsia, } \\
\text { antinausea, } \\
\text { antiflatulent } \\
\text { incontinence } \\
\text { galactogogue }\end{array}$ & $\begin{array}{l}\text { Contact dermatitis } \\
\text { Weak antispasmodic } \\
\text { activity }\end{array}$ & Disulfiram & $\begin{array}{l}\text { Pregnant, } \\
\text { breastfeeding due to } \\
\text { antispasmodic effects }\end{array}$ \\
\hline $\begin{array}{l}\text { Blessed thistle* } \\
\text { (Cnicus benedictus) }\end{array}$ & $\begin{array}{l}\text { Stimulates menstruation, } \\
\text { antidiarrheal, } \\
\text { antibacterial, } \\
\text { expectorant } \\
\text { galactogogue }\end{array}$ & $\begin{array}{l}\text { Nausea, vomiting } \\
\text { diarrhea, contact } \\
\text { dermatitis }\end{array}$ & $\begin{array}{l}\text { Antacids, } \mathrm{H} 2 \\
\text { antagonists, proton } \\
\text { pump inhibitors, } \\
\text { sucralfate, insulin }\end{array}$ & $\begin{array}{l}\text { Pregnant and } \\
\text { breastfeeding }\end{array}$ \\
\hline $\begin{array}{l}\text { Fennel* (Foeniculum }^{*} \text { (vulgare) } \\
\text { vilgen }\end{array}$ & $\begin{array}{l}\text { Expectorant } \\
\text { Antispasmodic } \\
\text { URTI }\end{array}$ & $\begin{array}{l}\text { Seizures } \\
\text { Nausea, pulmonary } \\
\text { edema }\end{array}$ & $\begin{array}{l}\text { Anticonvulsant } \\
\text { Sun exposure }\end{array}$ & Unknown \\
\hline $\begin{array}{l}\text { Fenugreek* } \\
\text { (Trigonella } \\
\text { foenum-graecum) }\end{array}$ & $\begin{array}{l}\text { GI complaints } \\
\text { URT congestion } \\
\text { Antidiarrheal }\end{array}$ & $\begin{array}{l}\text { Uterine stimulant } \\
\text { Hepatotoxicity } \\
\text { Maple-syrup Urine } \\
\text { diarrhea }\end{array}$ & $\begin{array}{l}\text { Anticoagulants } \\
\text { Antidiabetics }\end{array}$ & $\begin{array}{l}\text { Pregnancy (uterine } \\
\text { stimulant) } \\
\text { breastfeeding }\end{array}$ \\
\hline $\begin{array}{l}\text { Goat's rue (Galega } \\
\text { officinalis) }\end{array}$ & $\begin{array}{l}\text { Diuretic } \\
\text { Galactogogue } \\
\text { Antihyperglycemic }\end{array}$ & $\begin{array}{l}\text { Headache weakness } \\
\text { nervousness }\end{array}$ & None reported & $\begin{array}{l}\text { Caution for children, } \\
\text { pregnant, and } \\
\text { breastfeeding patients }\end{array}$ \\
\hline $\begin{array}{l}\text { Milk thistle* } \\
\text { (Silybum marianum) }\end{array}$ & $\begin{array}{l}\text { Dyspepsia, liver damage from } \\
\text { chemicals }\end{array}$ & $\begin{array}{l}\text { Nausea, vomiting } \\
\text { diarrhea }\end{array}$ & $\begin{array}{l}\text { Aspirin, cisplatin, } \\
\text { disulfiram, } \\
\text { hepatotoxic drugs }\end{array}$ & $\begin{array}{l}\text { Pregnant or } \\
\text { breastfeeding patients }\end{array}$ \\
\hline
\end{tabular}

Nursing Herbal Medicine Handbook, Nursing Drug Handbook Series, Springhouse Pennsylvania.

* Often herbs are used in combination, such as mother's milk tea, various combinations of fenugreek, blessed thistle, anise, coriander, fennel, marshmallow and other herbs.

decision making to supplement with formula, discontinue breastfeeding, or use of products that stimulate milk supply.

Galactogogues include prescription and over-the-counter (OTC) drugs, or complementary and alternative medications (herbal supplements). In the United States, it is estimated that $15 \%$ of breastfeeding women have used herbal galactogogues but the extent of galactogogue use is unknown for Canadians [34]. The use of herbal galactogogues is cause for concern because users do not confide in their health care providers and may mix prescription, OTC, and herbal medications with potential for adverse effects $[35,36]$.

A number of herbal supplements are purported to have galactogogue properties (Table 2). In Canada, Koren et al. of the Motherisk Program, estimate that between 7 and 55\% of pregnant women use herbal supplements even though the safety and efficacy of these during pregnancy and lactation are unknown [37]. A recent American study surveyed herbal supplement use in pregnant women and reported the 14\% of users did not consider herbal remedies as medications but natural and therefore benign [38, 39]. However, herbal supplements often lack standard dosing and preparation, and known composition [40]. Published research is scant supporting herbs' effectiveness in increasing milk production and more importantly their safety to mother and infant. Additionally, use of herbal medications may not be disclosed to conventional health care personnel and clients may use both prescriptions and herbal supplements courting potential adverse reactions. While there is some evidence to support the safety and efficacy of select prescription drugs, much less exists for herbal supplements, and little is known regarding drug/herbal supplements interactions [41].

Women consulting health care professionals for the perception of insufficient milk production may receive a recommendation to supplement with formula and/or to use a prescription medicine. Prescribing drugs for insufficient milk has recently gained popularity among physicians and nurse practitioners, although a lack of consensus persists regarding the efficacy of prescription galactogogues and their safety for infants [28, 30,31]. "Some providers may inappropriately recommend galactogogues prior to emphasizing the primary means of increasing the overall rate of milk synthesis (i.e., frequent feeding and complete milk removal at regular intervals)." [7, page 42]. 
The most commonly prescribed drugs are the gastrokinetic agent, domperidone, and the antiemetic, metoclopramide. Until 2010, increased milk production was an off-label use for domperidone in Canada but the Federal Drug Administration in the United States does not recommend it due to reports of arrhythmias in users and the possibility of adverse effects for infants [8, 42]. The side effects of domperidone, a dopamine antagonist, include an increase in prolactin levels, dry mouth, abdominal cramps, and headache $[4,33,34]$. Domperidone is thought not to cross the blood-brain barrier but is excreted in breast milk in low amounts [35]. Although infant exposure to domperidone is considered insignificant, evidence is scant [36]. Other drugs that have been used include antipsychotics such as sulpiride, chlorpromazine, and hormones including human growth hormone, thyrotropin releasing hormone (TRH), and oxytocin nasal spray (Table 1).

In preparation for submission of a national grant we conducted a pilot study in 2009 using a prospective cohort design with a convenience sample of mothers. The purpose of the pilot was to examine self-efficacy, perceived milk production, and lactating women's use of medication prescribed to increase breastmilk in a cohort of 18-40-year-old mothers over six months. The pilot allowed testing of the recruitment strategy and the demographic questionnaire. This study was approved by the Conjoint Health Research Ethics Board of the University of Calgary. Permission to access the community clinics was granted by the Director, Community Health Centres, Partnerships and Services, Alberta Health Services.

\section{Material and Methods}

A convenience sample of seventy-six mothers was recruited from parent drop-in clinics at six community health centres in Calgary, Alberta, during a three-month period. Women attended the clinics for breastfeeding support and well baby checkups. Participants were literate in English, and were breastfeeding or had attempted to breastfeed a singleton infant within the previous two months. Exclusion criteria included mothers with gestational diabetes, previous breast reductions or augmentations, illnesses such as breast cancer requiring mastectomy or extended breast lump biopsies, and those who did not have a telephone. Term, healthy babies were included in the study. Excluded from the study were babies less than 37 weeks gestation, those physically compromised, or those born with abnormalities that would affect breastfeeding such as cleft lip or palate. Participants identified by public health nurses and approached by research assistants were given a package of questionnaires assessing breastfeeding self efficacy, maternal perception of insufficient milk production, and use of galactogogues. They were surveyed again by telephone at 3 and 6 months after entry. If a woman weaned within the follow-up contact time, she was asked to complete the last set of questionnaires.

The Breastfeeding Self-Efficacy Scale, short-form (BSES) [43], measures a mother's perceived ability to breastfeed her baby. Breastfeeding self-efficacy (BSE) is defined as a mother's confidence in her perceived ability to breastfeed the baby [44]. Decreased self-efficacy is known to be involved in cessation of breast-feeding $[27,45]$. It has been shown to be associated with perceived insufficient milk production [30]. The Hill and Humenick Lactation Scale (HHLS) is a direct measure of the perception women have of their own milk production [46]. A demographic information sheet designed for this study collected data on variables known to affect breastfeeding, for example, type of delivery, family support, previous breastfeeding experience, preparation for breastfeeding, and formula use at hospital and at home.

The BSES short form is a 14-item self-report instrument where items are preceded by the phrase "I can always" and anchored with a 5-point Likert scale where $1=$ not at all confident and $5=$ very confident. Items are summed to produce a score ranging from 14 to 70 with higher scores indicating higher levels of breastfeeding self-efficacy [47]. The BSES has been used extensively for a decade with a variety of populations and is widely published. The shortform scale has established validity and reliability in English and three other languages $[43,44,47]$. The Cronbach's alpha coefficient for the English short form is 0.94 [43, 47].

Perceived milk production was measured using the HHLS. It examines maternal commitment, satisfaction, and perceived infant satiety [46]. The HHLS is a 20 -item selfreport instrument where all items are anchored with a 7point Likert scale where $1=$ strongly disagree and $7=$ strongly agree and can be used for subscale analysis. The three subscales show moderate to high internal consistency, Cronbach's alpha coefficients: 0.75 to 0.98 [48]. Items are summed to produce a score ranging from 20 to 140 with higher scores indicating higher levels of commitment and perceived infant satiety. It has been used with diverse populations over the last fifteen years and is widely published $[49,50]$.

Information was entered into PAWS version 17 (SPSS, Inc., Chicago, IL, USA). Descriptive statistics (means, standard deviations, frequencies, and percentages) were used to characterize the sample and describe sociodemographic characteristics. A correlation matrix was calculated to determine if any socio-demographic characteristics were significantly correlated with each of the dependent variables. Potential covariates included age, parity, education, marital status, prior experience breastfeeding, reported support for breastfeeding, use of formula in hospital, prenatal class attendance, type of delivery, level of education, support, and preparation for breastfeeding (i.e., prenatal classes). Chi square test was used to explore the relationships between categorical demographic variables. The generalized estimating equation (GEE) was used to estimate multiple predictors for BSES and HHLS. This is considered an appropriate method to identify predictors in repeated measures studies. Known predictors of breastfeeding continuation such as delivery experience, prenatal classes, access to breastfeeding information, and support for partner and family were controlled for in the model. All comparisons were calculated with statistical significance set at a $P<0.05$. 
TABLE 3: Sample characteristics $N=76$.

\begin{tabular}{|c|c|c|}
\hline Variable & $\begin{array}{c}\text { Number } \\
\text { of } \\
\text { women }\end{array}$ & $n \%$ \\
\hline \multicolumn{3}{|l|}{ Marital status } \\
\hline Married & 60 & 79 \\
\hline Other & 16 & 21 \\
\hline \multicolumn{3}{|l|}{ Education years } \\
\hline High school & 14 & 18 \\
\hline Trade school & 4 & 5 \\
\hline Postsecondary & 55 & 72 \\
\hline \multicolumn{3}{|l|}{ Type of delivery } \\
\hline Vaginal & 51 & 67 \\
\hline Cesarean section & 25 & 33 \\
\hline \multicolumn{3}{|l|}{ Prenatal classes } \\
\hline $\begin{array}{l}\text { Have you ever attended prenatal classes? } \\
\quad \text { Yes }\end{array}$ & 58 & 76 \\
\hline $\begin{array}{l}\text { Did you attend prenatal classes for this } \\
\text { pregnancy? }\end{array}$ & 40 & 53 \\
\hline Yes & & \\
\hline $\begin{array}{l}\text { Did you find prenatal information useful? } \\
\text { Yes }\end{array}$ & 67 & 88 \\
\hline \multicolumn{3}{|l|}{ Previous breastfeeding experience } \\
\hline Yes & 32 & 42 \\
\hline \multicolumn{3}{|l|}{ Formula received in hospital } \\
\hline Yes & 32 & 42 \\
\hline \multicolumn{3}{|l|}{ When the decision to breastfeed was made? } \\
\hline When I became pregnant & 26 & 34 \\
\hline I was always going to breastfeed & 44 & 58 \\
\hline After prenatal classes & 2 & 3 \\
\hline My partner and I discussed it & 4 & 5 \\
\hline
\end{tabular}

Totals may not add to $100 \%$ given missing data.

\section{Results}

On average the participants were 30 years old (range 1940 years), initiation of exclusive breastfeeding was reported by $57 \%$. At Time 1 , entry into the study, $83 \%$ reported breastfeeding and formula feeding and their babies were between 1 and 20 weeks old. Seventeen per cent were exclusively breastfeeding. Forty-seven per cent were still breastfeeding at Time 2 but also using formula. At the end of Time 3, almost one-third of participants reported use of domperidone during breastfeeding to increase milk production (Table 3).

Table 4 shows the parameter results for predicting BSES scores and independent variables. Women who used formula at any time had lower breastfeeding self efficacy than those who did not use formula $(P<0.05)$. Women reporting lower breastfeeding confidence used both formula and domperidone, two interventions undertaken to ensure their babies were fed but which may be reflective of the lack of confidence in the ability to exclusively breastfeed. Women who had confidence in their ability to breastfeed (high BSES scores) also had high perceived milk production scores (high HHLS scores).

Women $(n=32)$ who used formula had lower BSES scores than those who did not $(n=43, P<0.001,95 \% \mathrm{CI}=$ $-11.66,-3.66)$. Domperidone was reported by $28 \%$ of the participants. Those who used domperidone had lower BSES scores than those who did not $(P<0.05,95 \%$ CI $=-10.13$, $-1.15)$.

Women reporting lower breastfeeding confidence as measured by BSES used both formula and domperidone (Table 4). The GEE results showed that there was no significant association found between education, marital status, and formula use and HHLS scores.

A positive association between those who used domperidone and formula was found (Pearson chi square, test statistic $=6.87, \mathrm{df}=1, P<0.05)$. As years of education increased, BSES scores increased (95\% CI $=0.628,3.251$, $P<0.05)$. Also, prenatal classes specific in breastfeeding information increased BSES at Time 1 only $(P<0.05,95 \%$ $\mathrm{CI}=1.455,14.5)$.

\section{Discussion}

The rate of exclusive breastfeeding was low in our studya finding similar in many other international studies. Breastfeeding combined with formula feeding was the most commonly reported method of feeding over time. Domperidone was prescribed to one third of breastfeeding women in our study. We were unaware of the particular circumstances precluding prescription but our inclusion criteria removed preterm babies, re-lactating women and those with known health situations that would have knowingly affected breastfeeding or breast milk yield. There are reports of increasing domperidone prescription for mothers of preterm babies (<31 weeks) [51], but the healthy well educated mothers in our study were from the community and their babies were term ( $\geq 37$ weeks) so we found the rate of prescription use in our small study high.

We have reported a 33\% rate of surgical delivery and there may be some justification in using dopamine antagonists to raise serum prolactin levels in some women who have had a cesarean section as they may lack a significant rise in prolactin levels [52]. Substances that increase prolactin levels may be effective for those women with known low serum prolactin but this test is seldom, if ever, done. There may be women who are responders and nonresponders to dopamine antagonists but this would have to be determined by challenge.

We found that confidence in breastfeeding skills and perceived breastmilk production were positively correlated but we also report high use of domperidone. We were unable to determine if use of domperidone contributed to perceived breastmilk production. This likely had to do with our inability to access a sample of women earlier in the postpartum period and prior to use of domperidone. Women reported that prenatal classes specifically addressing breastfeeding had an important influence on self-efficacy early in the postpartum period, a finding supported earlier in 
TABLE 4: Parameter results for predicting BSES and independent variables.

\begin{tabular}{|c|c|c|c|c|c|}
\hline \multirow{2}{*}{ Parameter(s) applied with BSES } & \multicolumn{2}{|c|}{ 95\% Wald confidence interval } & \multicolumn{3}{|c|}{ Hypothesis test } \\
\hline & Lower & Upper & Wald chi-square & $\mathrm{df}$ & Sig. \\
\hline Education & .628 & 3.251 & 8.399 & 1 & 0.004 \\
\hline Formula use & -12.801 & -2.313 & 7.977 & 1 & 0.005 \\
\hline Formula use over time & .135 & 4.550 & 4.327 & 1 & 0.038 \\
\hline Specific prenatal breastfeeding classes & 1.455 & 14.513 & 5.745 & 1 & 0.017 \\
\hline
\end{tabular}

Level of significance $P<0.05$.

a Canadian sample of breastfeeding women [53]. We support consistency of breastfeeding information offered throughout the reproductive period, beginning in prenatal classes and extending into the postpartum period or as long as the woman continues breastfeeding.

Formula use was also associated with the use of domperidone. We found that the HHLS did not discern between combination feeding mothers and exclusively breastfeeding mother. Women can feel satisfied and confident while combining breastfeeding and formula to feed their babies; however this combination may decrease duration of breastfeeding [20].

4.1. Limitations. A limitation of this study is the small urban convenience sample of women from one region in Canada. Our sample recruitment was curtailed by the H1N1 pandemic at which time Canadian federal, provincial, and local health agencies recommended isolation for infants under 6 months who could not receive H1N1 immunization [54]. Women stopped attending the drop-in clinics and community clinic nurses were redeployed to H1N1 immunization clinics and our study ceased prematurely.

Nurses selecting women in the clinic may knowingly have suggested those women already using a galactagogue or those women who were motivated to participate in a breastfeeding study may have more readily self-selected to participate in this study, thereby creating selection bias.

In our study only one woman reported using a herb (fenugreek) to increase milk production, and this does not reflect the range of herbal use reported elsewhere [34]. We found higher education associated with higher breastfeeding self efficacy but this may be a reflection of our participants. Our study sample consisted of well-educated, sociallyadvantaged women with excellent medical access, attributes not shared by all breastfeeding women. Also, participants entered the study at various times postpartum and recall bias may have affected responses. The hospitals where our sample delivered were not Baby-Friendly accredited, which may have skewed the results of this pilot study as formula is readily available on the units. Mothers may have received the recommendation to supplement with formula in hospital which can decrease a mothers overall breastfeeding duration [20].

4.2. Implications for Practice. We recommend that for healthy term infants born to healthy mothers, prescription medication should not be a first-line response to maternal perceived insufficient milk production, a recommendation also held by the Academy of Breastfeeding Medicine [7]. The increase in prescription medications may indicate the acceptance of a "ready fix" subsequent to short assessment visits with physicians by anxious mothers [55]. Best practice indicates a physical examination, an assessment of a breastfeeding session, and an interview prior to suggesting a prescription medication to address perceived insufficient milk production $[10,55]$. By following best-practice guidelines, those women who are experiencing a physiological decrease in milk production will be appropriately identified as needing the pharmacological support to maintain adequate milk production. Our results concur with others: women with increased confidence in their breastfeeding ability are more likely to persist and are less likely to question their milk production [24-26, 56]. Combating perceived insufficient milk remains an ongoing challenge for all health care professionals working with breastfeeding mothers. Improving information to postpartum mothers directly related to milk supply (fullness, timing of feeds), measures of infant satiation (satiation cues, output), and growth spurts in infants may help some mothers address breastfeeding concerns. Stressing the importance of nighttime breastfeeding in the first eight weeks postpartum, when prolactin levels are the highest may also help to decrease mothers' perception of insufficient milk [55].

\section{Conclusion}

In 2011, Protocol 9 published by the Academy of Breastfeeding Medicine Protocol Committee stated that caution should be exercised when recommending drugs to assist initiation, maintenance, or augmentation of human milk synthesis. Stronger ties in hospital to Baby-Friendly standards, increased availability of education for health care professionals, and standard practice guidelines for breastfeeding assessment prior to medication introduction into the breastfeeding dyad may promote breastfeeding self-efficacy and increased satisfaction of mothers and healthier babies.

\section{Abbreviations}

BSE: Breastfeeding self-efficacy

BSES: Breastfeeding Self Efficacy Scale

FDA: Federal Drug Administration

HHLS: Hill and Humenick Lactation Scale

$\mathrm{H} 1 \mathrm{~N} 1$ : Influenza A virus subtype

LTM2: Listening to Mothers II

MES: Maternal Experience Survey

TRH: Thyrotropin releasing hormone. 


\section{Conflict of Interests}

There are no competing interest. The authors are responsible for the content and writing of this paper.

\section{Acknowledgments}

This paper was funded by the Faculty of Nursing, University of Calgary. The authors' sincere thanks go to Emmanuel Thompson for statistical expertise, Amy Jo Hobbs, Kristin Ruzicki, and Arsheen Dhalla.

\section{References}

[1] L. M. Gartner, J. Morton, R. A. Lawrence et al., "Breastfeeding and the use of human milk," Pediatrics, vol. 115, no. 2, pp. 496506, 2005.

[2] M. Boland, "Exclusive breastfeeding should continue to six months," Paediatrics and Child Health, vol. 10, no. 3, p. 148, 2005.

[3] Association of Women's Health, Obstetric, \& Neonatal Nurses, "Position statement on breastfeeding," 2008, http://www.awhonn/content.do?name=05_HealthPolicyLegislation/5H_PositionStatements.html.

[4] S. Ip, M. Chung, G. Raman, T. A. Trikalinos, and J. Lau, "A summary of the agency for healthcare research and quality's evidence report on breastfeeding in developed countries," Breastfeeding Medicine, vol. 4, supplement 1, pp. S17-S30, 2009.

[5] Public Health Agency of Canada, Canadian Perinatal Health Report, 2008, Ottawa, Canada, 2008.

[6] E. Declercq and B. Chalmers, "Mothers' reports of their maternity experiences in the USA and Canada," Journal of Reproductive and Infant Psychology, vol. 26, no. 4, pp. 295-308, 2008.

[7] M. Bunik, C. J. Chantry, C. R. Howard et al., "ABM clinical protocol \#9: use of galactogogues in initiating or augmenting the rate of maternal milk secretion (First revision January 2011)," Breastfeeding Medicine, vol. 6, no. 1, pp. 41-49, 2011.

[8] J. D. Gussler and L. H. Briesemeister, "The insufficient milk syndrome: a biocultural explanation," Medical Anthropology, vol. 4, no. 2, pp. 13-24, 1980.

[9] J. Newman and T. Pitman, Dr. Jack Newman's Guide to Breastfeeding, HarperCollins, Toronto, Canada, 2003.

[10] C. M. Betzold, "Galactagogues," Journal of Midwifery \& Women's Health, vol. 49, no. 2, pp. 151-153, 2004.

[11] T. Aono, K. Koike, and K. Kurrachi, "Effect of sulpiride on poor puerperal lactation," American Journal of Obstetrics and Gynecology, vol. 143, no. 8, pp. 927-932, 1982.

[12] A. A. Zuppa, P. Sindico, C. Orchi et al., "Safety and efficacy of galactogogues: substances that induce, maintain and increase breast milk production," Journal of Pharmacy \& Pharmaceutical Sciences, vol. 13, no. 2, pp. 162-174, 2010.

[13] E. W. X. Wan, K. Davey, M. Page-Sharp, P. E. Hartmann, K. Simmer, and K. F. Ilett, "Dose-effect study of domperidone as a galactagogue in preterm mothers with insufficient milk supply, and its transfer into milk," British Journal of Clinical Pharmacology, vol. 66, no. 2, pp. 283-335, 2008.

[14] M. L. Campbell-Yeo, A. C. Allen, K. S. Joseph et al., "Effect of domperidone on the composition of preterm human breast milk," Pediatrics, vol. 125, no. 1, pp. e107-e114, 2010.
[15] S. Semenic, C. Loiselle, and L. Gottlieb, "Predictors of the duration of exclusive breastfeeding among first-time mothers," Research in Nursing \& Health, vol. 31, no. 5, pp. 428-441, 2008.

[16] M. O'Brien, E. Buikstra, and D. Hegney, "The influence of psychological factors on breastfeeding duration," Journal of Advanced Nursing, vol. 63, no. 4, pp. 397-408, 2008.

[17] K. Wijndaele, R. Lakshman, J. R. Landsbaugh, K. K. Ong, and D. Ogilvie, "Determinants of early weaning and use of unmodified cow's milk in infants: a systematic review," Journal of the American Dietetic Association, vol. 109, no. 12, pp. 20172028, 2009.

[18] M. Neifert, S. DeMarzo, J. Seacat, D. Young, M. Leff, and M. Orleans, "The influence of breast surgery, breast appearance, and pregnancy-induced breast changes on lactation sufficiency as measured by infant weight gain," Birth, vol. 17, no. 1, pp. 31-38, 1990.

[19] K. M. Rasmussen, J. A. Hilson, and C. L. Kjolhede, "Obesity may impair lactogenesis II," Journal of Nutrition, vol. 131, no. 11, 2001.

[20] A. V. Holmes, P. Auinger, and C. R. Howard, "Combination feeding of breast milk and formula: evidence for shorter breast-feeding duration from the national health and nutrition examination Survey," Journal of Pediatrics, vol. 159, no. 2, pp. 186-191, 2011.

[21] R. Pérez-Escamilla, "Evidence based breast-feeding promotion: the Baby-Friendly Hospital Initiative," Journal of Nutrition, vol. 137, no. 2, pp. 484-487, 2007.

[22] M. S. Kramer, B. Chalmers, E. D. Hodnett et al., "Promotion of breastfeeding intervention trial (PROBIT): a randomized trial in the Republic of Belarus," The Journal of the American Medical Association, vol. 285, no. 4, pp. 413-420, 2001.

[23] S. Merten, J. Dratva, and U. Ackermann-Liebrich, "Do baby-friendly hospitals influence breastfeeding duration on a national level?" Pediatrics, vol. 116, no. 5, pp. e702-e708, 2005.

[24] W. B. Colin and J. A. Scott, "Breastfeeding: reasons for starting, reasons for stopping and problems along the way," Breastfeeding Review, vol. 10, no. 2, pp. 13-19, 2002.

[25] J. S. Taylor, P. M. Risica, and H. J. Cabral, "Why primiparous mothers do not breastfeed in the United States: a national survey," Acta Paediatrica, International Journal of Paediatrics, vol. 92, no. 11, pp. 1308-1313, 2003.

[26] J. Callen and J. Pinelli, "Incidence and duration of breastfeeding for term infants in Canada, United States, Europe, and Australia: a literature review," Birth, vol. 31, no. 4, pp. 285292, 2004.

[27] D. E. McCarter-Spaulding and M. H. Kearney, "Parenting selfefficacy and perception of insufficient breast milk," Journal of Obstetric, Gynecologic, \& Neonatal Nursing, vol. 30, no. 5, pp. 515-522, 2001.

[28] M. F. McCann, N. Baydar, and R. L. Williams, "Breastfeeding attitudes and reported problems in a national sample of WIC participants," Journal of Human Lactation, vol. 23, no. 4, pp. 314-324, 2007.

[29] R. Blyth, D. K. Creedy, C. L. Dennis, W. Moyle, J. Pratt, and S. M. De Vries, "Effect of maternal confidence on breastfeeding duration: an application of breastfeeding self-efficacy theory," Birth, vol. 29, no. 4, pp. 278-284, 2002.

[30] K. Otsuka, C. L. Dennis, H. Tatsuoka, and M. Jimba, "The relationship between breastfeeding self-efficacy and perceived insufficient milk among Japanese mothers," Journal of Obstetric, Gynecologic, \& Neonatal Nursing, vol. 37, no. 5, pp. 546555, 2008. 
[31] Y. Y. Huang, J. T. Lee, C. M. Huang, and M. L. Gau, "Factors related to maternal perception of milk supply while in the hospital," The Journal of Nursing Research, vol. 17, no. 3, pp. 179-188, 2009.

[32] I. B. Ahluwalia, B. Morrow, and J. Hsia, "Why do women stop breastfeeding? Findings from the pregnancy risk assessment and monitoring system," Pediatrics, vol. 116, no. 6, pp. 14081412, 2005.

[33] S. M. Chan, E. A. S. Nelson, S. S. F. Leung, and C. Y. Li, "Breastfeeding failure in a longitudinal post-partum maternal nutrition study in Hong Kong," Journal of Paediatrics \& Child Health, vol. 36, no. 5, pp. 466-471, 2000.

[34] The National Children's Study, "Use of herbal products in pregnancy, breastfeeding and childhood workshop," 2003, http://www.nationalchildrensstudy.gov/about/stayinginformed/listserv/studyassemblymeetings/2003Dec/Pages/agenda_ 122003.aspx\#day3.

[35] K. N. Woodward, "The potential impact of the use of homeopathic and herbal remedies on monitoring the safety of prescription products," Human and Experimental Toxicology, vol. 24, no. 5, pp. 219-233, 2005.

[36] T. M. Bush, K. S. Rayburn, S. W. Holloway et al., "Adverse interactions between herbal and dietary substances and prescription medications: a clinical survey," Alternative Therapies in Health and Medicine, vol. 13, no. 2, pp. 30-35, 2007.

[37] G. Koren, J. J. Dugoua, L. Magee et al., "MotherNature: establishing a Canadian research network for natural health products (NHPs) during pregnancy and lactation," Journal of Alternative and Complementary Medicine, vol. 14, no. 4, pp. 369-372, 2008.

[38] K. Abascal and E. Yarnell, "Botanical galactagogues," Alternative and Complementary Therapies, vol. 14, no. 6, pp. 288-294, 2008.

[39] S. Zaffani, L. Cuzzolin, and G. Benoni, "Herbal products: behaviors and beliefs among Italian women," Pharmacoepidemiology and Drug Safety, vol. 15, no. 5, pp. 354-359, 2006.

[40] T. W. Hale, Medications and Mother's Milk, Hale, Amarillo, Tex, USA, 13th edition, 2008.

[41] P. O. Anderson and V. Valdés, "A critical review of pharmaceutical galactagogues," Breastfeeding Medicine, vol. 2, no. 4, pp. 229-242, 2007.

[42] Federal Drug Administration, "FDA talk paper: FDA warns against women using unapproved drug, domperidone, to increase milk production," 2009, http://www.fda.gov/Drugs/ DrugSafety/InformationbyDrugClass/ucm173886.htm.

[43] C. L. Dennis, "The breastfeeding self-efficacy scale: psychometric assessment of the short form," Journal of Obstetric, Gynecologic, \& Neonatal Nursing, vol. 32, no. 6, pp. 734-744, 2003.

[44] C. L. Dennis and S. Faux, "Development and psychometric testing of the breastfeeding self-efficacy scale," Research in Nursing \& Health, vol. 22, no. 5, pp. 399-409, 1999.

[45] C. L. E. Dennis, "Identifying predictors of breastfeeding selfefficacy in the immediate postpartum period," Research in Nursing \& Health, vol. 29, no. 4, pp. 256-268, 2006.

[46] P. D. Hill and S. S. Humenick, "Development of the H \& H Lactation Scale," Nursing Research, vol. 45, no. 3, pp. 136-140, 1996.

[47] K. Wutke and C. L. Dennis, "The reliability and validity of the Polish version of the breastfeeding self-efficacy scale-short form: translation and psychometric assessment," International Journal of Nursing Studies, vol. 44, no. 8, pp. 1439-1446, 2007.
[48] B. Punthmatharith and J. Singh, "A psychometric assessment of the $\mathrm{H} \& \mathrm{H}$ lactation scale in a sample of Thai mothers using a repeated measurement design," Nursing Research, vol. 54, no. 5, pp. 313-323, 2005.

[49] L. P. Lewallen, "A review of instruments used to predict early breastfeeding attrition," The Journal of Perinatal Education, vol. 15, no. 1, pp. 26-41, 2006.

[50] J. A. Lewis, "Maternal perceptions of insufficient milk supply in breastfeeding," American Journal of Maternal Child Nursing, vol. 34, no. 4, p. 264, 2009.

[51] O. P. da Silva, D. C. Knoppert, M. M. Angelini, and P. A. Forret, "Effect of domperidone on milk production in mothers of premature newborns: a randomized, double-blind, placebocontrolled trial," Canadian Medical Association Journal, vol. 164, no. 1, pp. 17-21, 2001.

[52] E. Nissen, P. Gustavsson, A. M. Widström, and K. UvnäsMoberg, "Oxytocin, prolactin, milk production and their relationship with personality traits in women after vaginal delivery or Cesarean section," Journal of Psychosomatic Obstetrics and Gynaecology, vol. 19, no. 1, pp. 49-58, 1998.

[53] Public Health Agency of Canada, What Mothers Say: The Canadian Maternity Experiences Survey, Ottawa, Canada, 2009, http://www.phac-aspc.gc.ca/rhs-ssg/pdf/survey-eng.pdf

[54] Alberta Health Services, "Pandemic (H1N1) 2009 Influenza vaccine," 2009, http://www.albertahealthservices.ca/hp/if-hptr-en-h1n1-vaccination.pdf.

[55] J. Riordan, Breastfeeding and Human Lactation, Jones \& Bartlett, Mississauga, Canada, 3rd edition, 2004.

[56] K. Sakha and A. G. Behbahan, "Training for perfect breastfeeding or metoclopramide: which one can promote lactation in nursing mothers?" Breastfeeding Medicine, vol. 3, no. 2, pp. 120-123, 2008. 


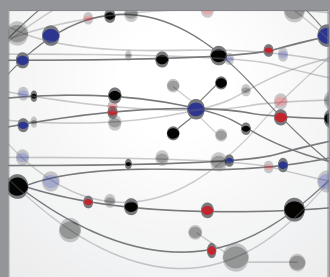

The Scientific World Journal
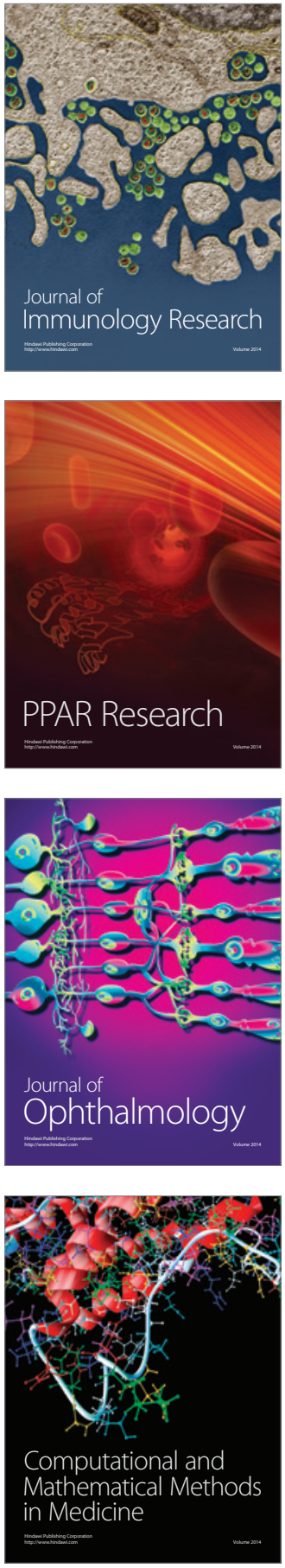

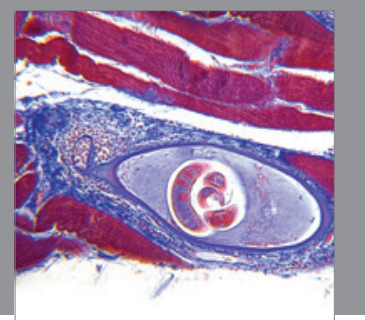

Gastroenterology

Research and Practice
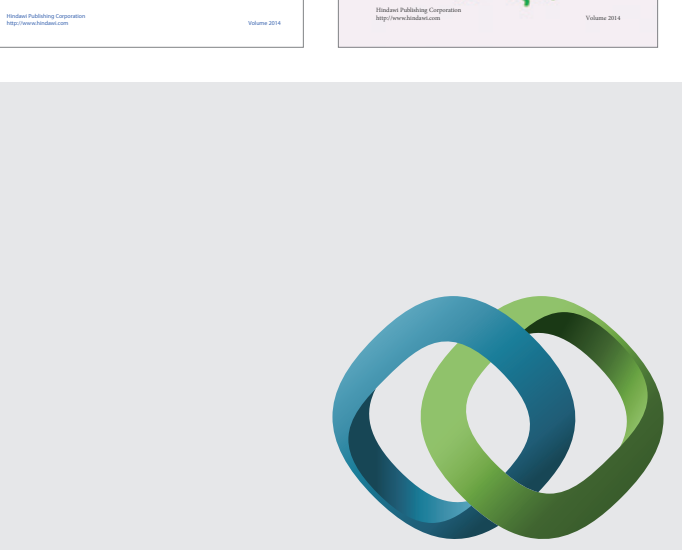

\section{Hindawi}

Submit your manuscripts at

http://www.hindawi.com
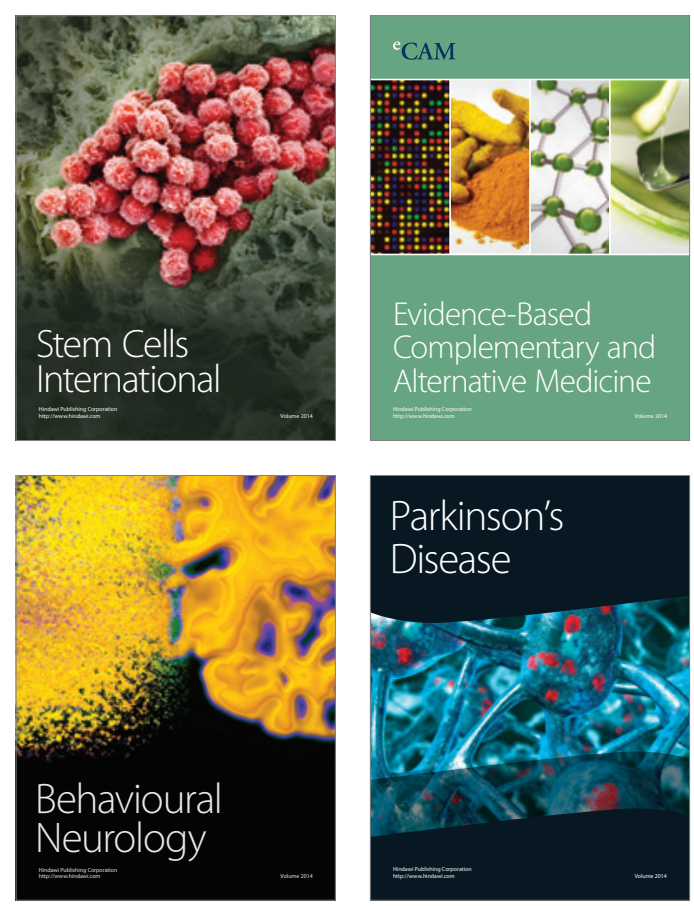

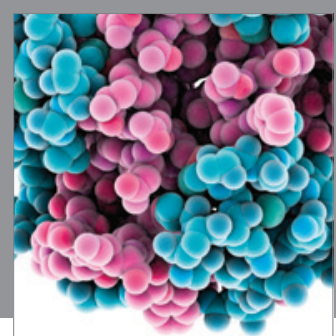

Journal of
Diabetes Research

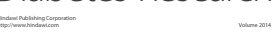

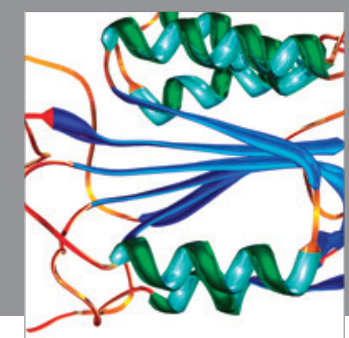

Disease Markers
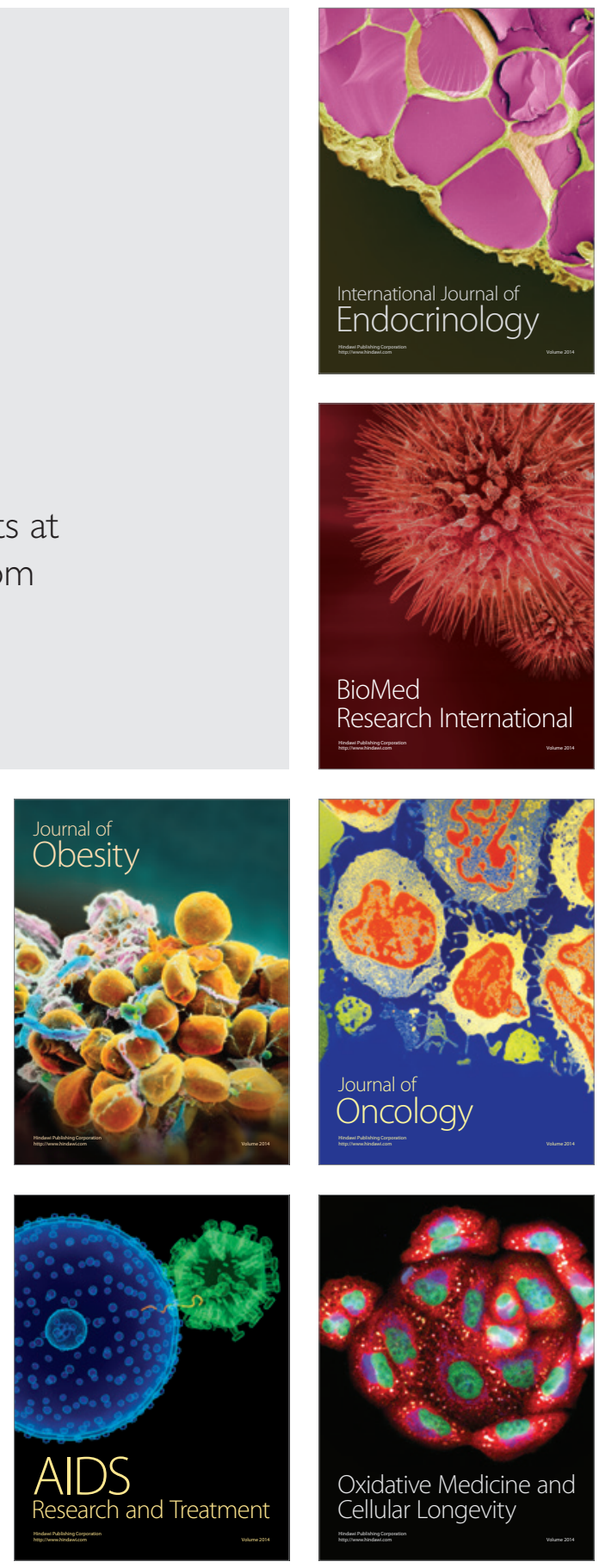